\title{
THE EFFECT OF MAPPING MIND METHOD IN TEACHING ENGLISH AS A FOREIGN LANGUAGE FOR SPECIAL NEEDS LEARNERS
}

\author{
Assist. Prof. Dr. BAAN JAFAR SADIQ \\ College of Education \\ Baghdad University
}

https://doi.org/10.37602/IJSSMR.2020.3603

\begin{abstract}
The research aims to investigate experimentally mapping mind method in teaching EFL on special needs learners. The sample of the research is 3 Down syndrome and Autism learners from 3-6 years. Mapping mid method is not new but the new is teaching Down syndrome and Autism learners English foreign language in Iraq. Down syndrome and Autism children are considered special needs, they have some delete in production skill. Therefore, the challenge is to teach special needs learners English language through mapping mind method, which is focused on the association the word with picture or illustration. Thus, the word easily can be learned and memorized. It has hypothesized that there is no significant differences among the sample of the research in learning English through this method. The research has applied observations as a tool of collecting the data. The results have shown amazing developing in acquiring English foreign language. The sample could response and product English words although they could not produce Arabic words as much as they could in English. Thus, the null hypothesis of the research is rejected and the research has recommended teaching the slow learners and Down syndrome learners English language through this method.
\end{abstract}

\subsection{INTRODUCTION OF THE RESEARCH}

\subsection{The Problem of the Research}

Special needs learners need special instructional pacing, frequent feedback, corrective instruction, and modified materials, all administered under conditions sufficiently flexible for learning to occur. Special needs learners usually have low IQ; also their most obvious characteristic is a limited attention span compared to more able students. To keep these students actively engaged in the learning process requires more than the usual variation in presentation methods (direct, indirect), classroom climate (co-operative, competitive), and instructional materials (films, workbooks, co-operative games, simulations). If this variation is not part of your lesson, these students may well create their own variety in ways that disrupt your teaching. Other immediately noticeable characteristics of special needs learners are their deficiencies in basic skills (speaking, reading, writing, and mathematics), their 


\section{International Journal of Social Sciences and Management Review}

difficulty in comprehending abstract ideas, and most disconcerting, their sometimes unsystematic and careless work habits.

Thus, the current research use mind mapping method to improve the learning process and solve these difficulties. Instead of wasting students' time and effort having them memorize letters, words and ideas, we could clue them into something they could use pictures, illustration, diagram and use these things again and again to learn.

\subsection{The Aim of the Research}

The research aims at investigating experimentally the effect of mapping method in teaching English as a foreign language for special needs learners.

\subsection{The Hypothesize of the Research}

It is hypothesized that there is no statistically significant difference among the observations of the experimental group.

\subsection{The Value of the Research}

The values of the research have summed to the following:

1. Special needs learners are neglected from special education and methods of teaching English as a foreign language in Iraq which are the two branches should investigate their problems. Iraqi policy of teaching special needs students has deleted the foreign language from their learning Sadiq (2017). Thus, the current research has revealed the special needs learners and investigates the problem of their learning.

2. Special needs learners have many difficulties more than normal students therefore they need more studies focused on their difficulties and tries to solve them.

3. The current research has paved the way for special needs methods of teaching English foreign language.

4. The importance of this research lies in the fact that using a specific method in teaching English could assist in enhancing special needs students' acquiring another language.

5. The results of the research will be useful to guide the Iraqi Ministry of Education and policymakers to take the decision to teach special needs learners another language instead of insisting to follow the traditional subjects.

6. The results will guide teachers to use the right method to their special needs students instead of the traditional one and improving their quality of teaching.

7. It is hoped that the current research will make some contribution towards improving English teaching for Special needs students.

\subsection{Relevant Studies}

Zhany (2018) the study is aimed at exploring the relationship between explicit instruction of mind mapping at the pre-writing stage and the quality of Chinese EFL learners' argumentative writing. The study has used interviews to collect the data of the study. The 


\section{International Journal of Social Sciences and Management Review}

results have shown that the experimental group is better than the traditional method in teaching writing skill.

Sadiq (2017) the study is to investigate the use of total physical response for teaching slow learners. The sample of the study is also 3 special needs learners (down syndrome). The previous study has associated the English language with orders or instructions by using the physical responses. The method has proved its effectiveness in teaching the English language for the sample of the study.

Riahi (2017) this study attempts to study the effect of individual and collaborative mapping strategies on Iranian EFL learners' reading comprehension. The sample of the study is 90 students from pre-intermediate female students from 12-17 years were selected. The finding of the results, there is no statistical significance between the two strategies.

Teo, etal (2016) the aim of the study is to introduce lessons for young EFL learners to teach them reading skills according to using the map method. The learners at the end of the study could organize their ideas by drawing learner's concept maps.

\subsection{LITERATURE REVIEW}

In this chapter, the research has shown the mapping method and related studies.

\subsection{Reconstructive Approach}

"Reconstruct" means to build or create again (Procter, 1996:1202). Marshall and Rowland (1998: 2) state that students might construct a concept map or chart from the text. In this way they are manipulating the ideas and information, ensuring that they have a real grasp of the material.

It is a transformation approach to Sellers (2000: 5) who argues that to make information relevant and useful, students need to transform it in some way. Students need to take information out of its source text and put it into another form or a different format, i.e., creating a concept map, constructing a table or drawing a diagram, i.e., using visual organizers.

In addition, Nunan (1989: 35) states that to discriminate the more important information in a text from the supporting details and to organize this information in some way, students are encouraged to transform information contained in a text into diagrams, charts, etc.

\subsection{Visual Organizers}

Visual organizers are defined by Keeley (1998:1) as "simply drawings or formats used to represent information and to show relationships between ideas". On the importance of visual organizers, Keeley (Ibid.) states that visual organizers help students to think more critically and at higher levels of cognition, and process information at higher levels of comprehension, application, analysis, synthesis, and evaluation. In other words, they help students better understand and recall the information. Hamblin (1981: 49) argues saying that many pupils 


\section{International Journal of Social Sciences and Management Review}

learn better visually and that diagrams can be used to summarize and recall what has been read.

Johnson (1990:2), on the other hand, exemplifies how some of the most common visual organizers can be used with different types of conceptual relationships. For instance, a tree diagram can be used for classification, analysis, structure, etc. Charts can be used for comparison, contrast, generalization, etc... chain, can be used with the process, sequence, cause/effect and chronology. A sketch can be used with the physical structure, description of facts, space relationships, concrete objects and visual images. The timeline can be used to summarize and show the major events using the form of dates and events.

Most students, because of their significance in aiding comprehension and retention can use such visual organizers. Teachers and students should pay considerable attention to them and how to use them with different subject matters.

\subsection{The Concept of Mind Map}

Mapping is a method that uses comprehension/ concentration skills and evolves NT from which each fact or idea relates to every other fact or idea (Dhann, 2001: 8).To Maggie (1996:1) argues that mind mapping promotes active reading and listening, and encourages interaction with the information, which heightens and allows students to personalize the information to suit their particular needs.

Cave (2002:1) states that mind maps encourage right brain activity. They help you understand the structure of the information being learned. Seeing the big picture helps you notice how the various ideas relate to each other and sometimes connect the material to other ideas not presented by the author/ lecturer.

Demon (1994:4) believes that concept maps provide an extremely effective method of taking notes, which shows the structure of a subject and the relative importance of facts and ideas in addition to the facts themselves. Furthermore, it helps to associate ideas and make connections that could otherwise be too unrelated to be linked.

Stien (1988: 18) indicates that " it is a powerful device to improve memory, that can be used to preview, integrate or summarize information". The same usage is indicated by Germov and Williams (2002: 1) such as outlining a course, an entire text or a chapter in a text; taking notes on a lecture delivered by a holistic- styled instructor who may skip around from topic to topic, and providing an overview for study prior to tests.

\subsection{METHODS AND RESULTS}

This chapter has shown the procedures of the research to fulfil the aim of the research.

\subsection{Definitions of the Words}

The following variables are defined : 


\section{International Journal of Social Sciences and Management Review}

\subsubsection{Mapping Mind Method}

Buzan (1995: 320) mind maps are diagrammatic ways of organizing key ideas from texts and lectures which emphasize the interconnection of concepts and illustrate the relative hierarchy of ideas from title, to main concepts, to supporting details.

Most of the value of NT mind maps come from the process of creating them.

\subsubsection{Special Needs Students}

The term special needs learner is used to identify students who are seen as learning differently or having learning difficulties comes from a widespread institutional phenomenon (Williamson \& Paul, 2012: 93).

special needs learner refers to any students who were seen as struggling with the curriculum as well a more specific term used to describe students who were thought to be the largest subgroup of persons who fell into the category we now call mild to moderately intellectually disabled (Reynolds \& Fletcher-Janzen, 2006 cited in Ibid).

Currently, the special needs learner label is often used to frame students whose Intelligence Quotients the low average level I.Q. a score of between 75 and 90 (King, 2006: 2-3).

\subsection{Design of the Research}

The experiment design has been adopted to answer the aim of the research whether teaching English through total physical response is effective or not. The research has adopted "repeated measures design" for these reasons. This design can deal with the problem of nonrandomization through a repeated measures design, in which all tasks are given to a different individual in different times. Each participant's score at time 1 was compared with his/ her score at time 2.

Treatment (Mapping Method )... O 1...O 2...O3 ...(Mackey \&Gass, 2005:152).

\subsection{Sample Selection}

It has been taken Down syndrome children and Autism as special needs students. The sample of the research is (3) children at age of (3-6) years in Mama Mesoun Nursing and Kindergarten. (the number of the sample is only 3 children because the Iraqi policy in teaching does not allow to teach English until the accuracy of Arabic. Thus, most institutions did not agree to apply the research. The research is against the policy of the Ministry of Education. All special needs learner has special classes and institutions; the policy does not accept special needs learners in a normal class. In these classes, the teacher teaches them how to depend on themselves and they learn some numbers and word in Arabic that are necessary to keep them alive. The special needs learner classified according to their case as Down syndrome, Autism but they are kept in the same class whatever the age of the learner and their type are). The sample has matched in age, sex, case type (all of them are mild case type). 


\section{International Journal of Social Sciences and Management Review}

Volume: 03, Issue: 06 “November - December 2020"

ISSN 2582-0176

\subsection{Instructional Tools}

The research has been used observation tool to collect the information and data of the research. As Genesee\& Upshur (1998: 77-79) show that observation is basic to assess human skills and behaviours. Observation is an important aspect of foreign language research. Through observation teachers assess what students have and have not learned; they assess the effectiveness of particular teaching strategies and methods. Furthermore, the special needs learners have some difficulties in speaking as well as writing, therefore, observation is the best way to find results.

\subsection{Construction and Administration of the Experiment}

The experiment has lasted six weeks at Mama Maeson Nursing and Kindergarten. The experiment group has taught English through lessons of visual mapping (cards, puzzles, pictures).

The learners have exposed to English words through pictures cards and puzzles. The group of special needs learners has taken one hour of learning English lesson daily for the whole period of the experiment.

\subsection{Results}

The results observations have been analyzed, in order to determine whether there is a significant difference among the scores achievement of the sample. The results have shown that there are significant differences in the observation. This indicates that totally physical response is effective methods for learning slow learners, especially with Down syndrome learners. The sample has shown amazing development in the English language.

Table (1) Scores of the Sample through the Experiment

\begin{tabular}{|c|c|c|c|c|c|c|}
\hline sample & $\begin{array}{c}\text { Observation } \\
1\end{array}$ & $\begin{array}{c}\text { Observation } \\
2\end{array}$ & $\begin{array}{c}\text { Observation } \\
3\end{array}$ & $\begin{array}{c}\text { Observation } \\
4\end{array}$ & $\begin{array}{c}\text { Observation } \\
5\end{array}$ & $\begin{array}{c}\text { Observation } \\
6\end{array}$ \\
\hline No.1 & $\mathbf{1}$ & $\mathbf{3}$ & $\mathbf{4}$ & $\mathbf{5}$ & $\mathbf{5}$ & $\mathbf{5}$ \\
\hline No.2 & $\mathbf{0}$ & $\mathbf{1}$ & $\mathbf{3}$ & $\mathbf{4}$ & $\mathbf{5}$ & $\mathbf{5}$ \\
\hline No.3 & $\mathbf{1}$ & $\mathbf{2}$ & $\mathbf{4}$ & $\mathbf{4}$ & $\mathbf{5}$ & $\mathbf{5}$ \\
\hline
\end{tabular}

The six observations are divided into two as the pre observations and post observations the $\mathrm{X}$ mean of the three observations are 1.05 and the standard deviations S.D is 0.235 while the $X$ mean of post observations is 4.27 and S.D is 0.563 . That means there are significant differences between the pre and post observations under 0.05 significant levels and freedom degree 2. 


\section{International Journal of Social Sciences and Management Review}

Volume: 03, Issue: 06 “November - December 2020”

ISSN 2582-0176

Table (2) The $\mathrm{X}$ mean, standard deviations between the pre and post observations

\begin{tabular}{|c|c|c|c|c|c|c|}
\hline Variable & \multicolumn{2}{|c|}{$\begin{array}{l}\text { Pre } \\
\text { observations }\end{array}$} & \multicolumn{2}{|c|}{$\begin{array}{l}\text { Post } \\
\text { observation }\end{array}$} & $\begin{array}{l}\text { Calculated } \quad \mathbf{T} \\
\text { Value }\end{array}$ & $\begin{array}{l}\text { Statistical } \\
\text { significant }\end{array}$ \\
\hline \multirow{2}{*}{$\begin{array}{l}\text { Total physical } \\
\text { responses }\end{array}$} & $\mathrm{X}$ & S.D & $X$ & S.D & \multirow[t]{2}{*}{4.459} & \multirow[t]{2}{*}{ Significant } \\
\hline & 1.05 & 0.235 & 4.27 & 0.563 & & \\
\hline
\end{tabular}

The observations of the sample through the whole experiment have shown an interesting thing, that the whole sample of the research has acquired and produced English language (letters, colours, shapes, animals names..) instead of the Arabic language. Thus, the English language has taken just one lesson daily. As the results have shown teaching the English language through total physical responses are effective methods in teaching EFL for Down syndrome learners and Iraqi slow learners.

\subsection{Discussion of the Results}

The finding of the research has shown that mind mapping method is effective in teaching English as a foreign language for the sample of the research. These results are in s agreement with Sadiq (2017) that a previous study has shown that totally physical response is effective in English teaching for slow learners. Also, Zhany (2018) that the previous study has improved that mind mapping method is effective in writing skill, furthermore Teo, etal (2016) has revealed that mind mapping method is effective in teaching reading skill. However, the current research is against the findings of Riahi (2016) this previous study has explored that there are no statistically significant differences between individual and collaborate mapping.

The sample of the research has learned faster by associated the word with its picture even when they can not remember the letter or the word they remember the picture or the illustration. Thus, the word or letter has stored in mind effectively. The sample of the research is learned the English words more than Arabic words and they use the English language easier than Arabic words. Furthermore, the sample of the research has expressed themselves by using English words rather than Arabic which is more difficult for them. Thus, the sample has been calmer by express their needs in English.

\subsection{Conclusions}

The research has concluded that mapping method is suitable for special needs students and it has an effect in acquiring English foreign language. Finally, Down syndrome and Autism learners can learn English faster than the Arabic one.

\subsection{Recommendations and Suggestions}

The research is recommended MM. for teaching the learners, especially Down syndrome children and Autism. Also, the results of the research have shown amazing development in 


\section{International Journal of Social Sciences and Management Review}

Volume: 03, Issue: 06 “November - December 2020"

ISSN 2582-0176

acquiring the English language therefore, the Iraqi Ministry of Education could be recommended to teach English to this neglecting sample and showed little respect with the slow learners who can learn and could be an effective member of Iraqi society.

The research has suggested making other research on this sample Down syndrome because they are neglected from Special Education studies and TEFL. Also, the researchers might be investigated using other methods in teaching English for Down syndrome learners.

\section{REFERENCES}

Carter, R. \&Nunan, D. (2002) 4th Ed. The Cambridge Guide to Teaching English to Speakers of Other Languages. U.K.: Camprdge University Press.

Crystal, D. (1997) The Cambridge Encyclopedia of Language. 2nd . Great Britain: Cambridge University Press.

Freeman, D. (2000) Techniques and Principles in Language Teaching. 2nd. Ed. UK: Oxford University Press.

Genesee.F.\&Upshur , J. (1998) Classroom- based Evaluation in Second Language Education. U.S.A. :Cambridge University Press.

Harley, T. (2008) The Psychology of Language from Data to Theory. 3rd. Edit. U.S.A.: Psychology Press.

King, E. (2006). School Psychologist Files. Retrieved from http://www.schoolpsychologistfiles.com/slowLearnerFaq.html

Kumaravadivelu, B. (2008) Understanding Language Teaching: from Method to Postmethod.New Jersey: Taylor \& Francis e-Library.

Mackey, A. \&Gass, M. (2005) Second Language Reserch: Methodology and Design. U.S.A.:Lawrence Erlbaum Associates, Inc.

Murcia, Marianne,C. (2001) Teaching English as a Second or Foreign Language. 3rd Edit. U.S.A.: Heinle\&Henile.

Nunan, D. Second Language Teaching \&Learning.U.S.A: Heline\&Helinle Publishers.

Riahi, Zahra (2017) Effective Reading Comprehension in EFL Contexts: Individual and Collaborative Concept Mapping Strategies. Vol.8, No.1, Februrary 2017. http://dx.doi.org/10.7575/aiac.alls.v.8n.1p.51

Richards,J. \&Renandya, W. (2002) Methodology in Language Teaching: An Anthology of Current Practice. U.S.A.: Cambridge University Press.

Richards, J. \& Rodgers, T. (2001) Approaches and Methods in Language Teaching. 2nd Ed. Cambridge: Cambridge University Press. 


\section{International Journal of Social Sciences and Management Review}

Volume: 03, Issue: 06 “November - December 2020"

ISSN 2582-0176

Reynolds, C., \& Fletcher-Janzen, E. (2006). Encyclopedia of Special Education A Reference for Children, Adolescents and Adults with Disabilities and Other Exceptional Individuals. Hoboken: John Wiley and Sons.

Sadiq, Baan (2017) Total Physical Response in Teaching English Foreign Language for Iraqi Slow Learners. Global Proceedings Repository American Research Foundation. https://doi.org.10.24897/acn.64.120 .

Sciarini, N. \& Steinberg, D. (2006) An Introduction to Psycholinguistics. 2nd. Edit. Great Britain: Pearson Longman.

Teo, Adeline; Shaw, Yun; Chen, Jimmy; and Wang, Derek (2016) Using Concept Mapping to Teach Young EFL Learners Reading Skills. English Teaching Forum. American English state.gov/English-teaching-forum.

Williamson,J. \& Paul, J. (2012) The Slow Learner as Mediated Construct. Candian Journal of Disability Studies. CJDS (August).

Ur, P. (1996) A Course in Language Teaching: Practice and Theory. Great Britain: Cambridge University Press.

Zhany, Ying (2018) A Contrastive Study on the Application of Mind Maps in Argumentative Writing Instruction for EFL. English Language Teaching Vol.11, No.12,2018: Canadian Center of Science and Education. https://doi.org/10.5539/elt.v/ln2p93/ .

Appendix (1) Observation Sheet for Rating the Sample Response

\begin{tabular}{|c|l|}
\hline Rating Scale & \multicolumn{1}{|c|}{ Item Response } \\
\hline 5 & Excellent response with face, signs and oral repetition \\
\hline 4 & Appropriate response to audience/ situation/ instruction \\
\hline 3 & General appropriate response to audience/ situation/ instruction \\
\hline 2 & Somewhat appropriate response to audience/ situation/ instruction \\
\hline 1 & General inappropriate response to audience/ situation/ instruction \\
\hline 0 & No evidence that functions were preformed \\
\hline
\end{tabular}

